Article

\title{
Good Urban Governance and City Resilience: An Afrocentric Approach to Sustainable Development
}

\author{
Natanya Meyer $1, *$ (1) and Christelle Auriacombe ${ }^{2}$ \\ 1 WorkWell Research Unit, School of Management, Faculty of Economics and Management Sciences, \\ North-West University, Vanderbijlpark 1900, South Africa \\ 2 School of Public Management, Governance and Public Policy, University of Johannesburg, \\ Auckland Park 2006, South Africa; christellea@uj.ac.za \\ * Correspondence: natanya.meyer@nwu.ac.za; Tel.: +27-82-347-6611
}

Received: 6 July 2019; Accepted: 5 September 2019; Published: 5 October 2019

\begin{abstract}
Good urban governance is a multidimensional concept that focuses on the improvement of the quality of living conditions of local citizens, especially those of marginalised and disadvantaged communities. Cities face various adversities and challenges, such as unsustainable use of natural resources, lack of housing and infrastructure, the prevalence of poverty, rapid urbanisation, crime, disasters and effects of climate change. City resilience is an inclusive process that refers to a city's ability to sustainably manage unexpected and expected risk-related events. In addition, it includes a city's capacity to adapt to future challenges from a strategic and spatial perspective. This paper aims to analyze the nature of sustainable development in general. More specifically, it sets out to analyze the importance of urban governance in Africa and the interrelationship of good urban governance and city resilience. The purpose is to provide a theoretical underpinning and a practical orientation for the role that urban governance could play in sustainable development. The methodology is based on a document analysis by way of an intensive literature study. The qualitative description of the findings focused on the themes that emerged from the research and the manner in which they were conceptualised. It was established that while African countries have experienced certain successes, there have been many challenges as far as 'good' and 'sustainable' urban governance is concerned. Results indicated that the notion of 'good urban governance' is a prerequisite for African countries to design and execute sustainable development initiatives successfully.
\end{abstract}

Keywords: Africa; city resilience; local governance; sustainability; sustainable development; urban governance; urban resilience

\section{Introduction}

Good urban governance and sustainable development are closely interlinked. As such, urban resilience is viewed as an important outcome of good urban governance. This article focuses on the local levels of governance. Within this context, urban governance is confronted with complex issues such as waste disposal, housing, low tax bases, unemployment, sanitation and water purification, electricity, the construction and maintenance of roads and other challenges associated with rapid urbanisation. In general, sustainable development interventions are implemented via these service delivery programmes. As such, citizen dissatisfaction is mostly experienced at this level of governance. Local governments in general are responsible to foster sustainable livelihoods and to ensure urban centres' resilience. Good urban governance can be regarded as a prerequisite for growth and prosperity in communities. Furthermore, socio-economic growth should be facilitated by good urban governance and so lead to an environment in which communities are capable to create more sustainable livelihoods [1,2]. 
Van der Waldt [1], states that there is a close relationship between urban governance and city resilience. City administrations must foster resilient urban communities through effective scenario development and city planning, environmental protection and the optimal utilisation of scarce resources. Urban resilience not only focuses on the resilience of metropolitan cities, but also includes towns and smaller living areas. Specifically, it pertains to urban communities' ability to absorb future shocks and stresses to social, economic, and technical systems and infrastructure to maintain the same functions, structures, systems and identities [1,3].

Obeng-Odoom [4] states that the term 'urban governance' cannot easily be defined due to its different dimensions, contexts and applications. Notably, this is the case in developmental states. According to De Wet [5], some authors highlight spatial planning dimensions, while others focus on the decentralization of power, local entrepreneurship (e.g., how to attract investment), economic development, and local democratization (e.g., participating in local decision-making processes) to conceptualize urban governance. From a sustainable development perspective, urban governance focuses on the role of local partnerships to bolster socio-economic and political development within urban communities [6]. This could be implemented by applying urban resilience principles and using technical instruments [7]. Van Der Waldt and Auriacombe [8] state that, urban governance can thus be regarded as a city-wide approach to improve the contribution of urban areas to economic growth, social development, poverty reduction, and the protection of the environment. Hence, urban governance has many interpretations and can therefore be viewed as an umbrella concept.

In recent years, there has been a transition from urban management to urban governance [8]. Urban management was primarily concerned with the effective, efficient, and economical use of resources to provide services with an internal organizational focus and considered issues such as municipal structures, administrative systems, planning processes, and policy implementation procedures of importance [8]. This notion was criticized as too narrow in focus where internal organizational efficiency was prioritized instead of the broader community issues [9]. Conversely, urban governance has extensive governance concerns and incorporates both urban management and government (that is, municipality or local authority) $[8,10]$. The United Nations (UN) spearheaded this shift when it established the Global Campaign for Good Governance in 2001 [8]. The UN promoted urban governance as a viable avenue to improve urban communities' living conditions by advocating for collaborations and partnerships between urban government, civil society, non-governmental organizations (NGOs), the private sector, as well as regional and international agencies $[6,11,12]$.

\section{Rationale for the Study}

As mentioned, good urban governance is a multidimensional concept that focuses on the improvement of the quality of living conditions of local citizens, especially those of marginalised and disadvantaged communities. Globally, cities in developed and developing countries are under tremendous pressure to keep up with rising populations, lack of resources, and subsequent events resulting from this situation. However, it seems that cities in developing countries are facing more challenges compared to well-developed ones in more developed countries. As such, understanding this concept of the interrelationship between good urban governance and city resilience and how to sustainably manage unexpected and expected risk-related events can prove valuable in the development and implementation of policies, especially in developing countries. Therefore, having a clear understanding of the important aspects linked to this topic can greatly improve the way it is managed.

\section{Purpose of the Study}

This paper aims to analyze the nature of sustainable development in general. More specifically, it sets out to analyze the importance of urban governance in Africa and the interrelationship of good urban governance and city resilience. The purpose is to provide a theoretical underpinning and a practical orientation for the role that urban governance could play in sustainable development. 


\section{Materials and Methods}

Considering the rationale of the study and its conceptual and contextual nature regarding good urban governance as a multidimensional concept, the study aimed to investigate the theoretical underpinning of the role it can play to promote sustainable development. Considering the research design, this study utilized a qualitative research approach by way of unobtrusive methods, as it was considered the most suitable approach to gain insights and understanding of a phenomenon (in this case the relationship between good urban governance and city resilience). Several unobtrusive qualitative research methods are available and conceptual and documentary analysis was selected in this case to build a theoretical framework. A theoretical framework is important to obtain clarity about the relationships between elements or issues in a given phenomenon. A conceptual framework emerges after a thorough theoretical exploration. This reveals the scope of concepts, assumptions, expectations, beliefs, and theories that support and inform the investigation. A conceptual analysis can be seen as a "system of concepts, assumptions, expectations, beliefs, and theories informing the research and is generally regarded as an explanation proposed to reach a better understanding of the social reality/phenomena that is being investigated" [13]. Documentary analysis allowed for a critical examination of content (numerical or non-numeric data) collected from trustworthy and reliable documents that have been compiled by industry experts in the specific field, in this case public management experts. Several studies and reports were carefully selected linking to the main aim of this study. In selecting these studies, the keywords sustainability, good governance, urban governance, city resilience and Africa were used. From the results, several studies were selected and then systematically reviewed to identify themes and concepts in terms of the aim of the study. Themes were extrapolated based on the discussions and concepts that were repetitive throughout the selected sources of information. Bowen [14] states that this approach allows for a systematic technique where various documents are reviewed and evaluated to extract important themes emanating from the research question or problem. Corbin and Strauss [15] opine that this method can help improve the understanding of the topic at hand. This method significantly reduces interviewer bias and sampling errors from primary data collection methods and it may thus be considered a credible research method [16]. Conceptual and documentary analysis are social research methods and the rationale behind the use of these methods is to triangulate information [14]. The information generated was scrutinised through a process of intellectual analysis, categorization, integration, reflection, and synthesis during which meanings were attributed to the data. After closely scrutinising authoritative sources, the authors concluded that the goal of qualitative science is twofold: first to develop concepts in order to get a better grasp on the phenomena represented by the concepts themselves and, second, from this, to develop generalizable and valid theories or analytical frameworks. These research activities, primarily those involving interpretation, conceptualisation and abstraction provide qualitative inquiry meaning and a legitimate place in the social sciences to contribute to new knowledge. Corroborating findings and information from different sources can create a confluence of information which could strengthen credibility [14].

Using this research design has many advantages. Firstly, it is less time consuming and less expensive than other qualitative methods such as interviews and observation. Secondly, most documents are available in the public domain and as no human interaction is involved, no informed consent from participants is required. Lastly, documents are easily accessible, reliable, and non-reactive, thus they can be reviewed several times without the influence of the researcher [14]. Document analysis is unobtrusive and therefore it eliminates the potential bias from interaction and promotes contextual and conceptual investigation [17-19]. Results obtained from the analysis allow for verification with specific reference to the various documents [20]. This study made specific use of academic textbooks, peer reviewed articles and published books on the study topic. As recommended by Bowen [14], these documents were selected as the contact contributed to the objective of the study, the documents could be deemed credible, authentic, complete, and representative and the source of the documents were known. The qualitative description of the findings focused on the themes that emerged from 
the research and the manner in which they were conceptualised. Information was compared and interpreted to find connections and variations between the themes and results that were generated.

\section{Literature Review and Background to the Study}

\subsection{Urban Governance and Sustainability in Africa}

Bello-Schúnemann and Aucoin [21] state that, Africa's future is urban. By 2030, it is expected that Africa will have six of the world's 41 megacities. The UN [22] defines a megacity as a city which has a population of 10 million or more people. Egypt's capital Cairo is Africa's largest megacity, with approximately 19.2 million people. Lagos, the capitol of Nigeria, is the continent's second-largest city, with 13.7 million inhabitants. Other emerging megacities on the continent include Kinshasa in the Democratic Republic of Congo (DRC), Johannesburg in South Africa, Luanda in Angola and Dar es Salaam in Tanzania [8]. Abidjan in Côte d'Ivoire and Nairobi in Kenya by 2040 are also expected to be megacities [21]. By 2050, six additional megacities are set to emerge, namely Ouagadougou in Burkina Faso, Addis Ababa in Ethiopia, Bamako in Mali, Dakar in Senegal, as well as Ibadan and Kano in Nigeria [8]. In addition, cities such as Accra, Abuja and Kampala also have the potential to rise as future megacities.

Globally, megacities encounter major challenges, for example, poor sanitation, lack of electricity, high crime rates, slums filled with substandard housing, joblessness, a lack of material resources, poverty, poor health care, homelessness and traffic congestion and a lack of education facilities [23]. In Africa, these challenges are amplified by poor infrastructure, limited resources and slow economic growth. Sustainable urban development is high on Africa's development agenda because the rate of urbanization has almost doubled since the early 1990s [8]. However, pervasive poverty, inequalities, climate change, and poor urban spatial planning have hampered cities' ability to become more resilient [24].

According to Bello-Schúnemann and Aucoin [21] the African continent has the world's highest annual average urban population growth rate, at approximately 3.9 percent. Currently, about 488 million Africans live in cities. In 2050, it is estimated that close to 1.4 billion people (58\% of the continent's population) will be living in cities [21]. This places a significant burden on urban councils to provide adequate land for settlement, finances, infrastructure and other critical services-especially in the light of existing backlogs [8].

While North Africa is Africa's most urbanized region, East Africa has the highest current and forecasted annual urban population growth rate (4.5\% in 2016 and 3\% in 2050). As stated in Van der Waldt and Auriacombe [8], approximately 92 million people currently live in Nigeria's urban areas-the highest in Africa. People move to urban areas searching for employment and access to services. In Nigeria, economic growth has not translated into tangible improvements in citizens' living standards or access to jobs. Economic growth mainly occurred in industries with little benefit to the poor, such as oil production. Other highly urbanized countries in Africa include Egypt, South Africa, the Democratic Republic of the Congo (DRC), Algeria and Ethiopia [8].

Any analysis of Africa's status quo should consider the fact that countries on the continent are not homogenous. They differ vastly in terms of culture, belief systems, language, ethnicity, political regimes, geographical realities and economic growth trajectories [25]. As such, it is useful to divide Africa into five sub-regions, namely North, West, Central, East and Southern Africa. All regions have unique characteristics and priorities as far as sustainable development is concerned. Despite these differences, there is general consensus on the continent on what the main challenges are and how to address them [9].

According to the United Nations Economic Commission for Africa (UNECA) [26], the post-2015 development agenda for Africa is largely informed by Africa Rio +20 and the consultative processes that were carried out in the continent's five sub-regions. The Africa Rio+20 refers to the Africa Consensus Statement (20-25 October 2011) that is based on UN Resolution 64/236 [27]. Notably, the resolution 
aims to promote political commitment towards sustainable development among African countries and calls for the adoption of concrete measures and implementation structures to accelerate the execution of sustainable development commitments; including those adopted at Rio+20 [8].

The Africa Rio+20 originated as a result of the Arusha Declaration on Africa's Post-Rio+20 Strategy for Sustainable Development that was drafted at the 14th session of the African Ministerial Conference on the Environment (AMCEN) in Arusha, Tanzania [28]. The statement established a common approach to urban governance and therefore facilitates any evaluation of sustainable development governance in Africa. The New Partnership for Africa's Development (NEPAD), which was adopted in 2001 [29], is another commonality, as far as sustainable development and urban governance is concerned $[9,30]$. This comprehensive framework highlights peace, security, democracy, as well as good economic and corporate governance as preconditions for sustainable development in Africa [9,30]. Yet another positive development concerning urban governance in Africa was the establishment of the African Union (AU) in 2002 to play a key role in the execution of the continent's sustainable development agenda. The AU also helps to align continent-specific development priorities with the UN's development programmes [9,31]. Auriacombe [9] adds that this has helped improve governance in general and urban governance in particular. Furthermore, these positive developments have led some analysts to believe that Africa is at a sustainable development 'crossroads' as it continues to search for appropriate policies, government programmes, strategies and appropriate institutional mechanisms to improve citizens' quality of life. As such, it is imperative to assess Africa's progress with regard to the social, economic and environmental dimensions of sustainable development.

Although Africa is the least-developed region in the world, the continent holds extensive potential in several areas. For example, 40 percent of the world's potential hydroelectric energy and 12 percent of its natural gas can be found in Africa [32]. Moreover, the continent is home to the bulk of global diamond and chromium resources, as well as 50 percent of gold, 90 percent of cobalt, 50 percent of phosphates, 40 percent of platinum, and 8 percent of coal and global petroleum reserves respectively [32]. Furthermore, Africa has enormous agricultural potential, with millions of acres of latent farmland [29]. This leads to the following question: Why is Africa in this state? Ayittey [33] argues that there are two schools of thought regarding the question, namely the 'externalist' and the 'internalist'. Ayittey [33] and Van der Waldt [1] add that, the externalists attribute Africa's challenges to factors beyond its control, such as: colonialism and imperialism; exploitation by multinational corporations; conspiracy plots; an unjust and unequal global economic system; and inadequate flow of foreign aid, trade and investment.

Mazrui [34], for example, argues that almost all Africa's woes can be blamed on colonialism and imperialism, which harmed indigenous technological development. The author argues that Westernisation on the continent masquerading as modernity, political instability, and poor governance is the result of foreign governance systems that undermine African culture [34]. Political leaders often use this argument and blame international donor institutions such as the World Bank and the International Monetary Fund (IMF) for insufficient funding to improve the conditions of the poorer segments of society. Furthermore, externalists argue that poverty on the continent is mainly due to artificial colonial borders and racism $[9,33]$.

Conversely, internalists blame existing governance systems that are characterised by unnecessary state intervention in the economy, corruption, nepotism and maladministration. Mazrui [34] denotes this as vampire or pirate African states [1]. In general, internalists are fed up with leaders who use colonialism/imperialism as an excuse for their own failures [1,35].

Heywood and Achebe [36] takes a strong standpoint against blame-shifting and states that the trouble with Nigeria is simply and squarely a failure of leadership. Internalists list the following typical reasons for Africa's low growth trajectory:

- Poor political and administrative leadership;

- Poor governance and decaying public institutions;

- Systemic corruption; 
- Capital flight, economic mismanagement and declining investment;

- Civil wars and tribalism; and

- Political tyranny, human rights violations and military vandalism [1,37].

Internalists agree that external factors have influenced Africa's status quo. However, they argue that internal factors have been more important in determining the current state of Africa [38]. Notably, internalists argue that Africa can only be placed on a sustainable development path if power is taken away from the elite and given back to citizens [1,39]. Thus, the politics of inclusion must replace the politics of exclusion. For this to happen governance systems must be fully democratised and broad-based political reform must take place. Economic transformation is also important to liberate financial markets [40], to obtain foreign direct investment (FDI) and to ensure that Africa becomes globally competitive. Also, it is imperative to address issues relating to corruption, nepotism and maladministration. Within this context, independent and free media plays a vital role in exposing crime; facilitating the free flow of information, disseminating new ideas and promoting home-grown solutions to problems.

It is not easy to realise the multiple dimensions of good developmental urban governance. Internationally, local governments experience a dichotomy between democrats (political elected office-bearers) and technocrats (the bureaucracy). These two groups have their own focal points, speak a different language regarding functional responsibilities and in general mistrust one another [41,42]. To overcome these challenges as well as political factionalism and infighting, requires strong political and administrative leaders. Importantly, these leaders should work in unison towards achieving common vision and developmental outcomes to improve citizens' lives. A significant first step towards accomplishing good urban governance is for leadership to establish a united, harmonious, coordinated, and synchronised administration-council relationship [43].

Obeng-Odoom [4] states that, good urban governance transcends the boundaries of governments, making use of a cluster of ideas ranging from decentralisation, entrepreneurialism to democratisation. The author further cautions that care should be taken not to claim that urban governance is unrelated to urban management because [these concepts] share features such as the increasing privatisation of hitherto public domains and the fact that both are appendages of a 'modernist' view of running cities [4].

\subsection{Contextualizing and Conceptualizing City Resilience}

Urban areas are better placed as key drivers for economic and social development, as well as environmental governance. Globally, urban governance is increasingly viewed as the foundation of socio-economic development. In line with this trend, urban areas typically act as economic hubs and serve as growth engines [44]. Jacobs [45] confirms that urban systems provide the backbone for national development, as they are characterised by a flow of information, capital, energy, commerce and people. Metropolitan municipalities act as the nucleus of community life. Thus, city or town authorities should pursue policies and programmes that support a sustainable, viable and resilient concentration of social activities. This includes thorough spatial planning and local economic development (LED) strategies to make cities and towns attractive and competitive for development [46-49].

The specific development responsibilities of cities differ from country to country, depending on the level of decentralisation, the governance system and the country's constitutional mandate. Nonetheless, Mayer and Keyes [50], as well as Van der Waldt and Auriacombe [8] state that cities typically have certain generic development responsibilities. These include:

- Fostering local democracy through community participation and the establishment of democratic and accountable local governance systems;

- Building capacity for effective local service delivery;

- Leveraging development by expanding opportunities for job creation, economic growth and community empowerment; 
- Enhancing cooperative governance through synergetic local systems and the implementation of national and sectoral development strategies and programmes; and

- Utilising information and communication technology to improve service efficiency and effectiveness, enhance policy-making and managerial decision-making, increase community participation, as well as promote transparency and accountability.

Furthermore, cities can gain insight into urban governance best practice by strengthening ties with local and international councils with the same conditions and circumstances. In general, discussions regarding best practice give cities the opportunity to share policy-related experiences, the efficiency and effectiveness of services rendered and community engagement in development efforts.

City governments have a key role to play in sustainable development, as they serve as growth hubs and centres of excellence. Lafferty and Meadowcroft [51] argue that a country's ability to cope with global challenges like climate change, the loss of ecosystems and the depletion of natural resources, largely depends on how its urban societies interact with their respective environments. IUCN [52] and Van der Waldt [1] highlights that several international agencies and organisations have been established to help guide cities towards greater resilience; notable examples include Cities Alliance, Local Governments for Sustainability (ICLEI), United Cities and Local Governments (UCLG) and the Symbiotic Cities Network (formerly Resilient City Group) [1]. Collectively, various white papers, guidelines, strategies and approaches have been published to share international best practice and solutions for urban challenges $[1,53]$.

According to Sjöstedt [54], city resilience is a multidimensional concept that focuses on a city's ability to strategically and spatially adjust to meet the challenges of the future. Hence, it is important to absorb future shocks and stresses to their social, economic and technical systems and infrastructures, so as to still be able to maintain essentially the same functions, structures, systems, and identity [1]. This includes appropriate interventions to cope with:

- Waste management;

- Spatial planning and land management to promote conservation and biodiversity;

- Renewable energy such as solar, wind, and hydropower;

- Public transport systems; and

- Environmental education and eco-tourism $[1,55]$.

Cities and towns are made up of interdependent systems and subsystems. When one system fails, it could have a negative impact on other systems. As cities act as economic growth and development centres, a crisis could have a knock-on effect in bordering and rural areas that depend on urban markets and resources [56,57].

As such, an integrated, holistic urban management approach should be followed. Resilience planning and effective city governance helps ensure that the failure of a single system (e.g., a local government function) does not lead to the collapse of others $[8,50]$. They further argue that proactive systems thinking, is crucial in this regard.

To become more resilient, city administrations and councils must have the capacity to adapt to rapidly changing internal and external pressures and circumstances [58]. However, Cummings and Worley [59] highlight that conventional bureaucratic structures and practices tend to be too rigid to accommodate proactive actions in response to risks [60,61]. According to Portney [62] and Thiele [63] organisational agility has many challenges, such as:

- City councils' limited ability to understand and analyze potential future shocks, which could impact urban systems and structures;

- An inability to follow an integrated and holistic approach to the various sustainable development dimensions;

- Insufficient alignment between sectoral government policies and national, provincial, and local government strategies; 
- No shared sustainable development and economic growth vision between government, the private sector and civil society; and

- Limited capacity, including staff competency, resources and infrastructure.

According to Fournier [64], these challenges call for de-growth of urban areas in the interest of longer-term sustainability. Furthermore, cities should only manage what they can, given their resource and capacity base [64].

\section{Discussion on Themes Arising from the Document Analysis}

Local government as a sphere of government closest to communities is under tremendous pressure to address the development and services needs of citizens within countries. In addition to the inadequate delivery of services, a major challenge is the need to demonstrate that development programmes as contained in sustainable development policies and programmes are reaching intended targets and achieving desired results. The ultimate goal of these policies and programmes should be to realise sustainable livelihoods for communities in spite of major problems such as climate change, rapid urbanisation, declining natural resources, and low socio-economic growth. The creation of sustainable livelihoods should be the primary focus within the context of sustainable development and the ability of urban governments to deliver essential services and products through various external shocks and stresses. Urban resilience in this regard is essential for cities and towns to constantly adjust and adapt to rapidly changing environmental conditions.

The promotion of sustainable livelihoods generally follows a poverty reduction approach as opposed to a welfare approach. The welfare approach typically places emphasis on poverty alleviation by utilising mechanisms such as social grants and donations. Poverty reduction in contrast, considers more sustained and long terms solutions. Recent initiates in this regard focus on facilitation of access to human, financial, natural, social and physical assets as key components of community's sustainable livelihoods.

\subsection{Good Urban Governance}

According to Van der Waldt and Auriacombe [8] and Kotzé and French [65] the global discourse on urban management, governance and resilience is often characterized by the quest for the universal principles of good urban governance. It is evident that there is general consensus about the fundamental principles thereof. Notably, due to the diverse nature of countries' prevalent political ideologies, governance systems, cultures, values, ethics, and so forth, there is no universal measurement for what constitutes 'goodness' [66]. As such, the level of 'goodness' differs significantly between developing and more-developed countries. Furthermore, the key tools or instruments utilized to pursue good urban governance also portray unique approaches and applications [67]. In some countries such as Rwanda and Kenya, there is a strong focus on state decentralization and local autonomy. Within this context, decision-making power is decentralized from national government to local entities. The primary aim is to ensure that policies and decisions are based on unique community realities, including demographics, service delivery priorities, climate, local politics, industries, and other economic activities.

Local authorities need to design adequate, appropriate instruments and tools to give effect to the principles of good urban governance. These instruments and tools are further discussed in the discussion section, as highlighted in Table 1, should be integrated into the operational procedures of municipal administrations. 
Table 1. Instruments and tools for good urban governance.

\begin{tabular}{ll}
\hline Good Urban Governance Dimension & \multicolumn{1}{c}{ Instruments and Tools } \\
\hline & Open council meetings \\
& Ward committee systems \\
& Open local media \\
& Suggestion boxes \\
& Public forums \\
Community participation & Telephone hotlines \\
and stakeholder involvement & Promoting a sense of belonging and city vision \\
& Mayoral public meetings \\
& City referendums \\
& Public petitioning \\
& Participatory planning and budgeting sessions \\
& Capacity-building initiatives \\
& Administrative reform programs \\
& Continuous improvement exercises \\
& Sound labor relations \\
& Effective systems, processes and procedures \\
& Performance monitoring and incentives \\
& Effective resource allocation and utilization \\
Effective urban management & Use of information and communication technology \\
and municipal administrations & Applying control mechanisms \\
& External partners who monitor functions, decisions and activities \\
& Rigorous procurement and accounting policies and practices \\
& Enforceable codes of conduct for political leaders and officials \\
& Information disclosure \\
& Independent complaints procedures \\
& Diversity in tenders and suppliers \\
& Decentralized decision-making \\
& Access to economic opportunities \\
\hline & Council transparency and accountability \\
& \\
&
\end{tabular}

Source: (Authors construction).

As can be seen from Table 1, good urban governance can be achieved through community participation and stakeholder involvement, effective urban management and municipal administration and council transparency and accountability.

The 'goodness' of urban governments has always been one of the key themes in international transformation and public sector reforms. According to Van der Waldt and Auriacombe [8] and Njoh [68], Western colonial administrators and missionary organisations significantly influenced traditional African governance systems. According to Auriacombe [9] and Osterhammel [69], colonialism drastically affected the features of governance (including local governance systems and structures), educational systems, culture (for example, language, belief systems and traditions) and political processes. As such, the author states that, an analysis of urban governance in Africa is thus incomplete without a thorough interrogation of colonial history and other international drivers [9].

\subsection{Economic Resilience of Urban Communities}

Literature in the fields of Sustainable Development, Economics, and Governance reveal that countries need to apply good governance-including good urban governance-to speed up development. Countries can only grow and prosper when strong, stable governments ensure efficient public institutions, implement policy frameworks to steer development and create favourable conditions for fiscal growth. Other key variables include ensuring the safety of citizens, providing proper health care, maintaining peace, instilling the rule of law and fostering a stable business environment. When these fundamental governance principles are in place, foreign aid institutions as well as donor agencies will be more willing to provide assistance to alleviate poverty and assist with other social and security challenges. 
In South Africa, the cooperative governance system demands that local government act as co-developer of growth, wealth and prosperity. In line with this, municipal councils are mandated with stimulating and promoting local development. Moreover, they are responsible for implementing broader government development agendas such as poverty alleviation, job creation, economic growth and infrastructure development. However, municipalities depend on citizens, local business and other enterprises' willingness, or ability to contribute to the local economy. Also, local authorities need financial resources to render services, develop infrastructure and promote the local economy by way of LED strategies and programs, as well as municipal economic development agencies [70].

According to Tsatsire [71] and Meyer and Meyer [72], cities can use their political and economic influence to promote economic growth of communities by providing an environment that is conducive to investment, growth, and prosperity. Such an environment should be created with appropriate development strategies such as: place marketing and industrial recruitment; promoting and supporting small-, medium- and micro-enterprises (SMMEs); ensuring business retention, expansion and attraction; and facilitating networking and partnerships [71].

In recent years, countries have begun to focus on 'place-centred', 'community-based' and 'people-orientated' economic frameworks. The global financial crisis and social inequalities made economists realise the importance of fostering resilient local economies. With this approach, cities and towns are encouraged to promote and market their resources to attract investment. When urban governments develop a conducive environment for business growth and investment in local industries [9,73], it leads to job creation, property development and higher household incomes. It also creates a need for infrastructure and services, such as schools, clinics, and police stations. As such, this approach plays a key role in ensuring local communities' overall resilience.

On a macro-scale, domestic consumption (i.e., urban consumer spending) is the largest contributor to economic prosperity in Africa's major economies [9,74]. Johannesburg, for example, is responsible for 42.1 percent of Gauteng's provincial wealth, which in turn generates 38 percent of South Africa's gross domestic product (GDP) and in addition, more than 75 percent of major South African companies have their headquarters in and around Johannesburg [8]. As urbanisation drives infrastructure development, the construction industry has created 40 percent more employment opportunities over the past decade [75]. In this regard, local authorities should guide infrastructure development by focusing on long-term spatial planning [1,73]. For example, appropriate sites should be allocated for residential development, business/industrial areas, city centres, as well as recreational and waste disposal sites [76].

From an economic development point of view, Africa's diverse economies act as drivers for growth. Most countries on the continent fall into one of four broad economic clusters, namely diversified economies, such as South Africa and Egypt; oil exporters, such as Nigeria and Angola; transition economies, such as Uganda; and pre-transition economies, such as the DRC, Ethiopia, Mali and Sierra Leone [75,77]. Most of these cities are situated in countries which are classified as low-income developing by the United Nations country classification [78]. These types of economies generally determine the nature, scope and economic growth and development trajectory. The continent's five largest economies (in terms of GDP), namely Nigeria, South Africa, Egypt, Morocco and Tunisia, all have highly diverse economies. According to Leke et al. [75], a diversified/differentiated economy is a key catalyst for national development, as it features a broad basis of income generation and growth. Sectors like mining, manufacturing, domestic services (for example, construction, banking, telecommunications and retailing) and agriculture all contribute to the country's GDP [75].

International trends and events such as economic globalisation, technological progress, the signing of international treaties and trade agreements and the rise of global production systems have altered the way African countries plan and drive LED. Globalisation exposes even the most remote areas on the continent to the rest of the world. In line with this, Valler and Wood [79] argue that, Local authorities are increasingly regarded as pivotal sites of competitiveness in a new global economy. Furthermore, 
LED planning is more community-based and pro-poor in its approach [80]. Ackron, Auriacombe and Van der Waldt [70] highlight that LED strategies in Africa are interconnected with:

- Human capital development;

- Infrastructure development;

- Municipal functions and services;

- 'Leak-plugging' in the local economy; and

- Countries' export processing zones (EPZs), industrial development zones (IDZs), and spatial development initiatives (SDIs).

International and local scholars have conducted a number of studies on the development of African countries. Van der Waldt [1] provides the following summary:

- Agriculture is central: Currently, agriculture is the main form of production in most African countries and the primary source of income for most people. As such, both African governments and donors should prioritise this sector and ensure that it receives sufficient support.

- Policy changes are key: African governments should eliminate their bias towards import dependence and focus on building the continent's agricultural sector and diversifying its production base.

- Available resources should be managed: Excessive state control should be minimised to help optimise the use of scarce resources.

- Donors and recipients should work together to achieve reforms: Donor agencies must use increased dependence to press African governments to assume responsibility for aid and national resources. Non-project aid can provide the needed leverage in this regard.

When investigating the implementation of LED in Africa, one needs to consider similar activities around the world. LED in African countries cannot be analysed without considering how prevailing ideologies, political cultures and colonialism affected countries' economies. To prosper and develop, African countries should strive towards economic stability and democracy $[70,81]$.

\subsection{Socio-Political Resilience through Decentralization and Urban Engagement in Development Interventions}

A centralised governance system could lead to insufficient service delivery and a passive approach to civic responsibilities among citizens. This is due to the fact that national and provincial government are too far-removed from local needs to make a true impact in communities. Conversely, city and town councils are closely involved with the communities they serve. Notably, Tsatsire [71] states that local government can play a significant role in alleviating poverty and enhancing job creation. Participation in local affairs is an effective way to bolster local communities' confidence in government and enhance the principles of legitimacy and public accountability. Moreover, consultation and participation help improve local government services and promote the implementation of local development policies.

When citizens participate in government's decision-making processes, it helps improve local conditions. According to Donaghy [82], Avritzer [83] and the World Bank [84] participatory processes that follow a decentralised government system tend to increase pro-poor investment, lower poverty levels and improve citizens' quality of life. Moreover, participation has an educational dimension, as it improves citizens' understanding of governance structures, contexts and challenges. There are also arguments against participation, for example:

- The dichotomy between public interests and citizen opinion: Local needs may be in conflict with broader public interests at a national level. These may include ecological concerns, particular service priorities and expenditure. Thus, there is a risk of adopting policies that are antisocial or contrary to the public interest [1].

- The logic of organisation: An inclusive, ethical approach with effective communication structures should be followed to avoid conflict between citizens and experts/technocrats. As modern 
society consists of interdependent complex organisations, at least two types of knowledge are needed $[1,85]$. Type-one knowledge includes democratic decision-making processes that can be acquired through learning by doing. Type-two is the technical knowledge needed to make decisions and manage complex organisations. This specialised knowledge requires relevant education $[1,85]$.

- The problem of the non-participant: In most of the cases, participation takes place in public. However, some citizens express the need for privacy. Contemplative versus participatory life, and the need to avoid disagreements in a participatory democracy, argue for 'non-participation' or 'limited participation' as citizens' right [86].

- Policymaking in crisis: Participation requires time and may not be effective when quick decisions must be made. In the future, most policymaking will take place in crisis situations, which could cause conflict between the elites and the masses [87].

In certain countries, citizens show little interest in political (i.e., voting) and local government affairs. Local government is seen as a 'closed system', where citizens merely receive certain services but do not participate in service-related decisions [88]. Auriacombe [9] adds that often, power is vested in the bureaucracy and not in the electorate. In these government institutions, 'elites' are often not accountable to citizens. Public officials are viewed as 'masters' rather than 'servants' of the people. This capturing of political power ultimately leads to poor service delivery and apathy amongst citizens. A further challenge relates to 'compulsory' or 'manipulated' participation. Within this context, participation is made compulsory to sidestep citizens' political apathy. This manipulated participation leads to little commitment and ownership [89].

Based on the themes arising from the study analysis, Figure 1 represents a macro perspective of the requirements needed to ensure city resilience and sustainable development.

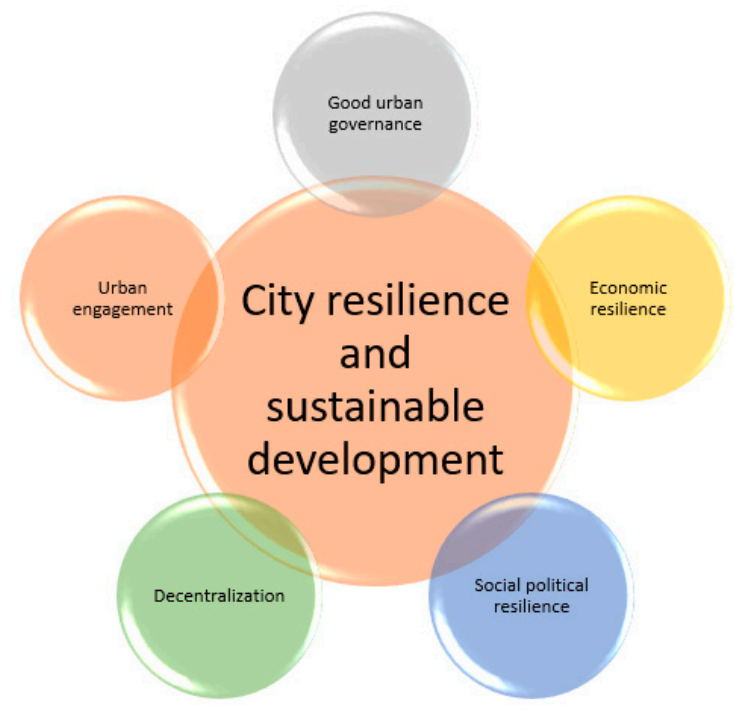

Figure 1. Factors leading to city resilience and sustainable development.

In this context, a rather macro perspective regarding good urban governance and sustainable development was followed. It is generally on the local levels of governance where sustainable development programmes are executed via service delivery projects (e.g., housing, roads, electricity, etc.) and where people acutely experience the level of goodness of governance. Local authorities are generally mandated to foster sustainable livelihoods and to enhance the resilience of urban centres. Any discourse about good governance and sustainable development is thus incomplete without incorporating the significant role that local or urban government plays, and should play, in this regard.

As was also established in this study, good urban governance and sustainable development are closely related. Good urban governance can be regarded as a prerequisite for economic resilience 
in terms of growth and prosperity in communities. Furthermore, good urban governance should facilitate socio-economic growth and thereby establish an environment in which communities can help themselves to create sustainable livelihoods. Urban governance has to contend with complex issues such as low tax bases, unemployment, waste disposal, water purification, housing, and other challenges associated with rapid urbanisation. Similarly, urban governance and city resilience are closely intertwined. Through effective scenario development and city planning, the protection of the environment, and the optimal utilisation of scarce resources, city administrations must foster the resilience of urban communities. Social political resilience is thus an essential outcome of good urban governance. Furthermore, good urban governance should facilitate urban engagement and thereby establish an environment in which communities can help themselves to create sustainable livelihoods. In addition, local governance reform generally led to the decentralisation and devolution of various powers and competencies to the local sphere of government. Decentralisation sanctions local authorities, including cities and towns, with certain political, administrative, and economic decision-making powers and autonomy. It entails the transfer of decision-making power and authority, as per the constitution and national legislation of a country, from central to local government. It brings government closer to the people, making government more responsive to the needs of communities, and fostering community participation in decisions affecting their daily lives. Hence, in this regard the focus of urban governance is on the facilitation of access to human, financial, natural, social and physical assets as key components of community's sustainable livelihoods in terms of the following key issues of urban governance:

- Political considerations (e.g., legitimacy, policy-making, public support);

- Technical capacity issues (e.g., service delivery, use of SMART technologies);

- Administrative arrangements (e.g., organisational structures, control mechanisms to curb maladministration and corruption; processes, procedures, methods);

- Environmental context (e.g., reduce negative impact through waste management and misuse of natural resources, neighbourhood resilience); and

- Social concerns and community engagement aspects (e.g., promoting local democracy, fairness in the distribution of benefits, services and products, crime prevention).

\section{Conclusions and Recommendations}

The purpose of this study was to lay a solid theoretical foundation, as well as a practical orientation for the role that urban governments should play in sustainable development. Emphasis was placed on the notions of "good" urban governance as a prerequisite for the ability and capacity of countries on the African continent to successfully design and execute development initiatives, to participate in the global economy, and to adhere to the imperatives emanating from international treaties and conventions as far as sustainable development is concerned. It was established that Africa experiences successes, but also major failures as far as good and sustainable urban governance is concerned. This paper provided a general overview of the role that cities and towns could and should play in sustainable development and community resilience. Globally, local governments have specific development responsibilities, as mandated by respective countries' constitutions. It was established that urban governance helps foster economic and socio-political resilience within local communities. Furthermore, the research highlighted that the decentralisation of development responsibilities and political decision-making helps ensure that local authorities are more responsive to community needs. In addition, the research found that networking and multi-stakeholder coalitions are a prerequisite for good urban governance. Stakeholders such as community wards, business, taxi associations, community- and faith-based organizations and the agricultural sector could help ensure that local councils make more balanced decisions. Moreover, multi-stakeholder coalitions help foster good urban governance and assist with performance oversight. 
The goodness of local or urban governance can be determined by measuring improvements in public policy outcomes. Internationally, there is a growing interest in measuring the success of public interventions by looking at how a target community's lives have improved rather than at the activities themselves. The sustainability of cities and the general level of sustainable development in countries are highly interrelated [51]. Urbanization places tremendous pressure on local authorities and city administrations to deliver essential services such as clean water, housing, transport, waste disposal and communication. Therefore, urban policy-makers and planners should consider the environmental impact of urban development, as rapid urbanization and environmental degradation go hand in hand.

Citizen education on how human settlements impact the environment plays a key role in improving the overall resilience of urban communities. It is of course not possible to educate all citizens, however any awareness making could contribute to the overall advancement and improvement of city resilience of urban communities. Furthermore, the current study highlighted the need for developing a body of knowledge on good urban governance and city resilience. These knowledge resources, and databases can help with capacity-building within city administrations. Future research should include an in-depth analysis of international best practice, as well as the development and implementation of policy guidelines, managerial checklists, benchmarks and performance standards which are equally important in this regard. Furthermore, the development of refined policy guidelines to assist local and international political decision makers would be beneficial to improve overall sustainable city development and resilience. Also, local government authorities should promote innovative practices to address the multitude of environmental challenges, such as environmental degradation, land tenure, spatial planning, informal settlements, and recreational facilities.

Author Contributions: C.A.: Conceptualization, formal analysis, Writing-Original draft preparation; funding acquisition. N.M.: Methodology, formal analysis, review and editing, project administration.

Funding: This research received no external funding.

Conflicts of Interest: The authors declare no conflict of interest.

\section{References}

1. Van der Waldt, G. Good Governance and Sustainability in Africa; University of Johannesburg Internal Handbook. MA Online Public Management; Governance and Public Policy; University of Johannesburg: Johannesburg, South Africa, 2018.

2. Nzeadibe, T.C.; Anyadike, R.N. Social participation in city governance and urban livelihoods: Constraints to the informal recycling economy in Aba, Nigeria. City Cult. Soc. 2012, 3, 313-325. [CrossRef]

3. Meerow, S.; Newell, J.P.; Stults, M. Defining urban resilience: A review. Landsc. Urban Plan. 2016, 147, 38-49. [CrossRef]

4. Obeng-Odoom, F. On the origin, meaning, and evaluation of urban governance. Nor. J. Geogr. 2012, 66, 204-212. [CrossRef]

5. De Wet, M.M.M. The variables influencing developmental local governance to promote sustainable communities and cities in South Africa. Ph.D. Thesis, University of Johannesburg, Johannesburg, South Africa, 2018.

6. Maloba, T.; Auriacombe, C.J. Citizen Participation in the Developmental State. Adm. Publica 2019, $27,1-15$.

7. United Nations Habitat. Urban Resilience Hub. Available online: http://urbanresiliencehub.org/trends2019/ (accessed on 12 October 2018).

8. Van der Waldt, G.; Auriacombe, C.J. CEP Module 3: Towards Sustainable Livelihoods; IQA: Johannesburg, South Africa, 2019; pp. 1-170.

9. Auriacombe, C.J. Government, Environment and Sustainable Development; UJ Internal Handbook; University of Johannesburg: Johannesburg, South Africa, 2014.

10. Gurran, N.; Bramley, G. Urban Planning and the Housing Market: International Perspectives for Policy and Practice; Springer: Berlin/Heidelberg, Germany, 2017.

11. Morris, R.J.; Trainor, R.H. Urban Governance: Britain and Beyond Since 1750; Routledge: Thames, UK, 2017. 
12. Fox-Kämper, R.; Wesener, A.; Münderlein, D.; Sondermann, M.; McWilliam, W.; Kirk, N. Urban community gardens: An evaluation of governance approaches and related enablers and barriers at different development stages. Landsc. Urban Plan. 2018, 170, 59-68. [CrossRef]

13. Auriacombe, C.J. Towards the construction of unobtrusive research techniques: Critical considerations when conducting a literature analysis. Afr. J. Public Aff. 2016, 9, 1-19.

14. Bowen, G.A. Document analysis as a qualitative research method. Qual. Res. J. 2009, 9, 27-40. [CrossRef]

15. Corbin, J.A.; Strauss, A. Basics of Qualitative Research, 3rd ed.; Sage: Thousand Oaks, CA, USA, 2008.

16. Stent, W.; Hooks, J.; Bradbury, M. New Zealand's switch to IFRS: Beyond the financial statements-A qualitative analysis of annual reports. Pac. Account. Rev. 2010, 22, 92-107. [CrossRef]

17. Babbie, E. The Practice of Social Research, 9th ed.; Wadsworth Thomson Learning: Belmont, CA, USA, 2001.

18. Webb, E.J.; Campbell, D.T.; Schwartz, R.D.; Sechrest, L. Unobtrusive Measures, 2nd ed.; Sage Publications: Thousand Oaks, CA, USA, 1999.

19. Huysamen, G.K. Methodology for the Social and Behavioural Sciences; Southern Book Publishers: Birmingham, UK, 1994.

20. Swart, J.J.; Swanepoel, M.J.; Surujlal, J. A critical analysis of government spending on sport. Afr. J. Phys. Health Educ. Recreat. Danc. 2014, 2, 251-265.

21. Bello-Schünemann, J.; Aucoin, C. African urban futures. Inst. Secur. Stud. Pap. 2016, 20, 1-36.

22. United Nations. The World's Cities in 2016. Available online: https://www.un.org/en/development/ desa/population/publications/pdf/urbanization/the_worlds_cities_in_2016_data_booklet.pdf (accessed on 17 May 2017).

23. Lucci, P.; Bhatkal, T.; Khan, A.; Berliner, T. What Works in Improving the Living Conditions of Slum Dwellers; ODI Dimenstion Paper; ODI: New York, NY, USA, 2015; Volume 4, pp. 1-40.

24. Fernández, I.; Manuel-Navarrete, D.; Torres-Salinas, R. Breaking resilient patterns of inequality in Santiago de Chile: Challenges to navigate towards a more sustainable city. Sustainability 2016, 8, 820. [CrossRef]

25. Idang, G.E. African culture and values. Phronimon 2015, 16, 97-111. [CrossRef]

26. United Nations Economic Commission for Africa (UNECA). Economic Report on Africa: Industrializing Through Trade. 2015. Available online: http://www.Uneca.Org/Publications/Economic-Report-Africa-2015 (accessed on 4 July 2016).

27. United Nations General Assembly. Resolution 64/236: Implementation of Agenda 21, the Programme for the Further Implementation of Agenda 21 and the outcomes of the World Summit on Sustainable Development. Available online: http://www.un.org/en/ga/search/view_doc.asp?symbol=A/RES/64/236 (accessed on 26 April 2017).

28. United Nations (UN) Economic and Social Council (ECOSOC). Committee Food Security and Sustainable Development. In Proceedings of the Eighth Session of the Committee on Food Security and Sustainable Development and Regional Implementation Meeting for the 20th Session of the Commission on Sustainable Development, Addis Ababa, Ethiopia, 19-21 November 2012; Available online: http://www.uneca.org/sites/default/files/uploaded-documents/CFSSD/CFSSD8/7._cfssd-80029-ore-progress-report-on-africa-regional-preparations-rio20.pdf (accessed on 5 May 2017).

29. United Nations (UN). Agriculture in Africa; NEPAD: Johannesburg, South Africa, 2013.

30. Waal, A.D. What's new in the New Partnership for Africa's Development? Int. Aff. 2002, 78, 463-476. [CrossRef]

31. Williams, P.D. The Peace and Security Council of the African Union: Evaluating an embryonic international institution. J. Mod. Afr. Stud. 2009, 47, 603-626. [CrossRef]

32. Hydroworld. Hydro in Africa: Navigating a Continent of Untapped Potential. Available online: https://www.hydroworld.com/articles/print/volume-21/issue-6/articles/african-hydropower/hydro-in-africanavigating-a-continent.html (accessed on 22 May 2019).

33. Ayittey, G. Africa in Chaos; Palgrave: New York, NY, USA, 1997.

34. Mazrui, A.A. The Africans: A Triple Heritage; Little Brown: Washington, DC, USA, 1986.

35. Ayittey, G.B.N. Sustainable Development: Promoting Progress or Perpetuating Poverty? Profile Books: London, UK, 2002.

36. Heywood, C.; Achebe, C. Chinua Achebe: Things Fall Apart: A Critical View; Collins in Association with British Council: London, UK, 1985. 
37. Ayittey, G.B.N. The “Colonialism-Imperialism” Paradigm Is Kaput. Available online: https://www.laits. utexas.edu/africa/ads/815.html (accessed on 22 May 2019).

38. Shitta-Bey, O.A. In defense of the internalists' conception of Africa's under-development. Int. Lett. Soc. Humanist. Sci. 2014, 26, 14-21.

39. Lawal, G. Corruption and development in Africa: Challenges for political and economic change. Humanit. Soc. Sci. J. 2007, 2, 1-7.

40. Pierzyna, J. The use of EU funding in the development of local economic activity zones. Forum Sci. Oeconomia 2019, 7, 85-102. [CrossRef]

41. Edigheji, O. Introduction: Public sector reforms and the quest for democratic developmentalism in Africa. Afr. Dev. 2008, 33, 1-13. [CrossRef]

42. Auriacombe, C.J. Public Sector Leadership; UJ Internal Handbook; University of Johannesburg: Johannesburg, South Africa, 2010; pp. 1-25.

43. Arifeen, M. Need of awareness about corporate social responsibility. Pak. Gulf Econ. 2012, 31, 1.

44. Phiri, A. Tourism and Economic Growth in South Africa: Evidence from linear and nonlinear cointegration frameworks. Manag. Glob. Transit. 2016, 14, 31-53.

45. Jacobs, J. Cities and the Wealth of Nations; Random House: New York, NY, USA, 1984.

46. United Nations Human Settlements Programme Ecoplan International (UN-HABITAT EPI). Promoting Local Economic Development through Strategic Planning; UN-HABITAT EPI: Nairobi, Kenya, 2005.

47. Meyer, N.; Meyer, D.F. An Econometric Analysis of Entrepreneurial Activity, Economic Growth and Employment: The Case of the BRICS countries. J. Econ. Manag. Perspect. 2017, 11, 429-441.

48. Meyer, D.F.; Masehla, T.M.; Kot, S. The relationship between economic growth and economic development: A regional assessment in South Africa. J. Adv. Res. Law Econ. 2017, 8, 1377-1385.

49. Sadaf, R.; Oláh, J.; Popp, J.; Máté, D. An Investigation of the Influence of the Worldwide Governance and Competitiveness on Accounting Fraud Cases: A Cross-Country Perspective. Sustainability 2018, 10, 588. [CrossRef]

50. Mayer, N.; Keyes, L. City Government's Role in the Community Development System; The Urban Institute: Washington, DC, USA, 2005.

51. Lafferty, W.M.; Meadowcroft, J. Implementing Sustainable Development: Strategies and Initiatives in High-Consumption Societies; Oxford University Press: Oxford, UK, 2000.

52. International Union for Conservation of Nature and Natural resources (IUCN). Caring for the Earth; IUCN Publications: Gland, Switzerland, 1991.

53. Moeletsi, J.M.D. An Investigation of the Barriers and Constraint Factors that Influence the Entrepreneurs in the Tourism Industry. Ph.D. Thesis, North-West University Vaal Triangle Campus, Vanderbijlpark, South Africa, 2004.

54. Sjöstedt, M. Resilience revisited: Taking institutional theory seriously. Ecol. Soc. 2015, 20, 23. [CrossRef]

55. Lakner, Z.; Kiss, A.; Merlet, I.; Oláh, J.; Máté, D.; Grabara, J.; Popp, J. Building Coalitions for a Diversified and Sustainable Tourism: Two Case Studies from Hungary. Sustainability 2018, 10, 1090. [CrossRef]

56. Bicknell, J.; Dodman, D.; Satterthwaite, D. Adapting Cities to Climate Change: Understanding and Addressing the Development Challenges; Earthscan: London, UK, 2009.

57. Meyer, D.F. Exploration of solutions for revitalisation of rural areas in South Africa. Mediterr. J. Soc. Sci. 2014, 5, 613. [CrossRef]

58. Golembiewski, R.T. Organizational development in the third world: Values, closeness of fit and culture-boundedness. Int. J. Public Adm. 1993, 16, 1667-1691. [CrossRef]

59. Cummings, T.G.; Worley, C.G. Essentials of Organization Development and Change; South-Western College Publishing: Sydney, Australia, 2001.

60. Oláh, J.; Kovács, S.; Virglerova, Z.; Lakner, Z.; Popp, J. Analysis and Comparison of Economic and Financial Risk Sources in SMEs of the Visegrad Group and Serbia. Sustainability 2019, 11, 1853. [CrossRef]

61. Vergotine, H.; Thomas, A. Enterprise risk management at South African state-owned companies. J. Contemp. Manag. 2016, 13, 674-701.

62. Portney, K. Civic engagement and sustainable cities in the United States. Public Adm. Rev. 2005, 65, 579-591. [CrossRef]

63. Thiele, L.P. Sustainability; Polity Press: Cambridge, UK, 2013. 
64. Fournier, V. Escaping from the economy: The politics of degrowth. Int. J. Sociol. Soc. Policy 2008, 11/12, 528-545. [CrossRef]

65. Kotzé, L.J.; French, D. The Anthropocentric Ontology of International Environmental Law and the Sustainable Development Goals: Towards an Ecocentric Rule of Law in the Anthropocene. Glob. J. Comp. Law 2018, 7 , 5-36. [CrossRef]

66. Crane, J.K.; Sandler, R. Natural, Artifactual, and Moral Goodness. J. Ethics 2017, 21, 291-307. [CrossRef]

67. Díaz-Díaz, R.; Muñoz, L.; Pérez-González, D. The Business Model Evaluation Tool for Smart Cities: Application SmartSantander Use Cases. Energies 2018, 10, 262. [CrossRef]

68. Njoh, A.J. Tradition, Culture and Development in Africa: Historical Lessons for Modern Development Planning; Routledge: Thames, UK, 2016.

69. Osterhammel, J. Colonialism: A Theoretical Overview; Markus Wiener Ill: Chicago, IL, USA, 2005.

70. Ackron, J.; Auriacombe, C.J.; Van der Waldt, G. Local Economic Development for Local Government; Internal Handbook for the Centre for Public Management and Governance (Module 5-HCLGM); University of Johannesburg: Johannesburg, South Africa, 2018.

71. Tsatsire, I. A Critical Analysis of Challenges Facing Developmental Local Government: A Case Study of the Nelson Mandela Metropolitan Municipality. Ph.D. Thesis, Nelson Mandela University, Port Elizabeth, South Africa, 2008.

72. Meyer, N.; Meyer, D.F. The relationship between the creation of an enabling environment and economic development: A comparative analysis of management at local government sphere. Pol. J. Manag. Stud. 2016, 14, 150-160. [CrossRef]

73. Layman, A.J. The Critical Elements of a Conducive Local Business Environment in Selected South African Municipalities. Ph.D. Thesis, University of Kwazulu Natal, Westville, South Africa, 2011.

74. McKinsey Company. What's Driving Africa's Growth. Available online: https://www.mckinsey.com/ featured-insights/middle-east-and-africa/whats-driving-africas-growth (accessed on 26 May 2019).

75. Leke, A.; Lund, S.; Roxburgh, C.; Van Wamelen, A. What's Driving Africa's Growth. Available online: http://www.mckinsey.com/global-chapters/middle-east-and-africa/whats-driving-africas-growth (accessed on 28 July 2016).

76. Clarke, E.; Nohrová, N.; Thomas, E. Delivering Change: Building Homes Where We Need Them; Delivering Change Report; L\&Q and Barratt Developments PLC: London, UK, 2014.

77. African Development Bank Group. East Africa Economic Outlook. 2018. Available online: https://www.afdb.org/fileadmin/uploads/afdb/Documents/Publications/2018AEO/African-EconomicOutlook-2018-East-Africa.pdf (accessed on 10 August 2019).

78. United Nations. World Economic Situation and Prospects; United Nation: New York, NY, USA, 2019.

79. Valler, D.; Wood, A. Conceptualizing local and regional economic development in the USA. Reg. Stud. 2010, 44, 139-151. [CrossRef]

80. Meyer, D.F. Quo Vadis: Jobs versus Economic Growth: Evidence from South Africa. J. Econ. Manag. Perspect. 2017, 11, 504-517.

81. Kumssa, A.; Mbeche, I.M. The role of institutions in the development process of African countries. Int. J. Soc. Econ. 2004, 31, 840-854. [CrossRef]

82. Donaghy, M.M. Do Participatory Governance Institutions Matter? Municipal Councils and Social Housing Programs in Brazil. Comp. Politics 2011, 44, 83-102. [CrossRef]

83. Avritzer, L. Living under a democracy: Participation and its impact on the living conditions of the poor. Lat. Am. Res. Rev. 2010, 45, 166-185. [CrossRef]

84. World Bank. Africa Development Indicators. Available online: http://data.worldbank.org/data-catalog/ africa-development-indicators (accessed on 22 September 2018).

85. Squier, M.M. The Principles and Practice of Knowledge Management. Ph.D. Thesis, University of Pretoria, Pretoria, South Africa, 2003.

86. Techau, M.; Lunde, A.; Pedersen, C.G.; Green, A.; Johannessen, H.; Nissen, N. Non-participants and reasons for non-participation in a pragmatic trial of energy healing as cancer rehabilitation. Eur. J. Integr. Med. 2014, 6, 268-276. [CrossRef]

87. Johnson, T. The Politics of Waste Incineration in Beijing: The Limits of a Top-Down Approach? J. Environ. Policy Plan. 2013, 15, 109-128. [CrossRef] 
88. Clarke, A.; Margetts, H. Governments and citizens getting to know each other? Open, closed, and big data in public management reform. Policy Internet 2014, 6, 393-417. [CrossRef]

89. Johnson, C. Local Democracy, Democratic Decentralisation and Rural Development: Theories, Challenges and Options for Policy. Dev. Policy Rev. 2001, 19, 521-532. [CrossRef]

(C) 2019 by the authors. Licensee MDPI, Basel, Switzerland. This article is an open access article distributed under the terms and conditions of the Creative Commons Attribution (CC BY) license (http://creativecommons.org/licenses/by/4.0/). 